\title{
EGYPTIAN WOMEN ARTISANS: ICTS ARE NOT THE ENTRY TO MODERN MARKETS
}

\author{
Leila Hassanin \\ Information and Communication Technology for Development in the Arab World ${ }^{1}$
}

\begin{abstract}
Handicrafts are an income generating activity for many women in Egypt, though as producers these women are often receiving the lowest return in the trading chain. This research analyses the potential for Egyptian craftswomen to use information and communication technologies (ICTs) to improve their earnings. The research shows that while ICTs could be a useful tool for marketing and selling their products, there are various structural challenges to trading via microICT outlets like websites to the international market. Though online sales of crafts are possible, the use of ICTs as a marketing outlet by the average craftswoman is not viable in today's Egypt. The findings show that in the case of handicraft trade the generic "export is best" attitude is not the solution. In fact, the global craft market is too competitive for the typical Egyptian craftswoman as they are generally not equipped to handle the global handicrafts business environment. If the purpose is to empower artisan women then it would be better to enhance the demands for Egyptian handicrafts among the average Egyptian and thus create a domestic market for these products.
\end{abstract}

Keywords: E-commerce, Egypt, artisans, ICTs

\section{Introduction}

The idea for this research began as a project need. ArabDev had been promoting the use of the Internet among low income target groups throughout Egypt with a special focus on women. Several of the women in the training courses began asking if ArabDev can assist them in selling their goods online. The women and various supporting not-for-profits wanted to explore this option as a way to improve their earnings which are slim when they go through the traditional trading route.

The requests were in line with a strong focus in Egypt to promote microenterprises and to make handicrafts exportable. Donors and development practitioners working for income generating activities have been focusing on

${ }^{1}$ www.arabdev.org

Please use the following format when citing this chapter:

Hassanin, L., 2008, in IFIP International Federation for Information Processing, Volume 282; Social Dimensions of Information and Communication Technology Policy; Chrisanthi Avgerou, Matthew L. Smith, Peter van den Besselaar; (Boston: Springer), pp. 179-190. 
micro- and small-enterprises (MSEs) as a tool for poverty alleviation. For example, the National Council for Women (NCW) in Egypt, presided over by the first lady, is spearheading income generation for rural women through handicrafts production. The council has trained 840 women in four governorates in craftmanshipand is tying this activity to traditional crafts. The products were showcased at the Global Summit of Women 2006 - the Davos for Women - in Cairo. The establishment of micro- and small-enterprises has been a poverty alleviation strategy for years in Egypt. Entrepreneurship is seen as a possibility for many people if they are given the adequate training. Through establishing their own businesses it is believed that females, even the ones who live in remote areas, can reach beyond their limitations and establish businesses.

According to this trend, development specialists believe that women will benefit by becoming entrepreneurs. But are the conditions for this entrepreneuroriented model realistic? Is "entrepreneurship" a learnable skill for most of these women? Or are main components missing to make this entrepreneurship model a reality? Or does this notion of entrepreneurship, self-sufficiency, and "can make it" attitude need certain contextual circumstances taking into account the constraints that lower income and lower educated women face $[4,5]$ ?

Egypt is planning to institutionalize e-commerce in coming years and therefore it was important to explore the potential of ICTs, the Internet especially, to market female crafts.

The study found that aside from the viability to use ICTs as marketing and selling tools, the underlying premise of micro entrepreneurship as a successful model for income generation is flawed. The findings question the assumption that women can be taught entrepreneurship, and that they can use ICTs successfully to improve their income. The research shows that ICTs were not widely used and, in fact, for many women constituted new sets of limitations, inequities, and barriers.

This concurs with Poojary's [2] findings that entrepreneurship is generally difficult to teach through training courses, but rather that entrepreneurial skills are learned from being in an entrepreneurial milieu. Therefore a person coming from an entrepreneurial family background is more likely to become an entrepreneur themselves [2].

The research concludes that an export oriented strategy for marketing crafts in Egypt is not a promising means to secure a better income for craftswomen. The Egyptian case study highlights the challenges faced by local craft producers who have a restricted domestic market for traditional, higher-end handicrafts. Increased local demand for their wares would make income generation easier for these craftswomen.

The findings show that ICTs are only a small part of the marketing cycle and that there are other fundamentals in the production and marketing process that are hindering exports of Egyptian handicrafts. The main barrier to micro-businesses by female artisans is the low of demand for Egyptian crafts in the domestic market. An Egyptian market for their crafts would make it more realistic for them 
to be able to establish independent businesses and local markets would make the use of ICTs as marketing tools feasible for some of the women artisans.

\section{Methodology}

The analysis is based on case studies of women and organisations working in the crafts sector. To market crafts through ICTs extensive back office procedures involving quality control, transportation, and customs, among others, are needed. The study therefore reviewed the regulatory and transport issues involved in crafts export and made a quick market analysis of the national and international craft business as far as it relates to the female handicraft sector in Egypt.

The study is based on a series of qualitative interviews conducted during 20052006, field observations, and years of community development practice using ICTs to enhance livelihoods and education in Egypt. The research used openended, life-story interviews to encourage women to go beyond the specific focus of ICTs. This enabled the research to assess the use of ICTs in the women's lives and it brought issues that were important for the interviewees as females struggling with various life challenges that would not have been included in a more structured ICT focused interview.

It was not easy to locate and contact the craftswomen. There was reluctance, if not outright avoidance, especially on the part of traders to give information about their women producers, let alone allow direct contact with them. The unwillingness was mostly out of protectionism by the merchants who did not want to disclose their production sources. Even non-governmental organisations (NGOs) working in the field had to be approached through work relations and acquaintances. Due to these circumstances the research relied mostly on craftswomen working with NGOs.

Additionally, there were very few cases where artisan women had a combined experience with handicrafts and information technology. The ones who were found are more the exception than the rule; there is a weak relationship between crafts, women, and ICTs in Egypt.

Ten women from different regions of Egypt were interviewed. Varying geographical locations were chosen to account for some of the sub-cultures in the society. The research covers interviewees from Cairo, the community of Coptic solid waste collectors "Zabaleen" in Old Cairo, Siwa, Aswan, and Helwan an industrial district south of Cairo. In addition to the interview some of the NGOs' staff where interviewed.

The Egyptian society is predominantly Muslim, with a Coptic minority. Muslim and Coptic informants were included, the research did not find, in its scope, a difference between women from either religion. Both Coptic and Muslim women are subject to the same traditional, patriarchal norms. Additionally, Nubian and Siwan females were included as they have distinct traditional crafts and historical backgrounds. 
Education ranged from university degrees to former illiterates, who through adult education attained diplomas. The interviewees' ages span from 18 to 53 years. Family conditions ranged from single, married, married with children, and separated. Financially, some of the women co-financed their households, some were saving the money in preparation for marriage, and one woman was the main provider for herself and her two children.

The study did not plan to extend beyond Egypt, but to comprehend the conditions for successful e-commerce for Egyptian craftswomen it was essential to understand the dynamics of the international crafts-market. I visited the New York Gift Fair, a major global crafts exhibit, to get a first hand experience of international competition.

\section{The female artisans}

The interviews highlighted the fact that ICTs are, at present, only marginally used in the production, marketing and selling cycle for female handicrafts in Egypt. Randa, who was illiterate until her late teens is now a daily user of the Internet but not directly to market handicrafts.

I used to be a weaver of rugs working with a local NGO. After I completed many years of literacy studies and I was able to earn my diploma I began working as a secretary for the NGO. That is when I stopped the weaving as I got a better income through my new job.

Asking Randa about how the NGO markets the rugs, she says that it is mostly done through traditional bazaars, a shop at the NGO, and contacts of the board members. She says that she sometimes takes questions for orders over email, but that the transactions are done via fax or in person.

Dalia has a B.A. in finance, she is a candle-maker, and wants to go into the wedding preparation business. Dalia is currently receiving training through a donor organisation $\left(\mathrm{COSPE}^{2}\right)$ in enterprise design and management.

The Internet is very useful for me. I own a computer and connect daily from home where I work. I browse online to get ideas for candle shapes. Lately I have been exploring to shift my business to wedding management as I am having a hard time finding the raw material for my candles. I sell the candles through fairs and at the Trade Egypt outlet. COSPE has a website but no orders ever came through the site. At present I do not see that there is enough demand to sell online.

Aida manages a recycled paper production line at an NGO. She sells paper products, cards, stationary, and artwork through an outlet located at the NGO and through fairs and direct contact with clients.

We do not sell online. Some of our contacts use emails for orders though, but it is more a follow up on the orders than new business.

\footnotetext{
${ }^{2}$ See: http://www.utlcairo.org/ong/COSPE/our_projects.htm
} 
We are browsing the net for ideas, but in general I would say that the Internet is not a major tool for us. I see the potential though and if you come back in some years we might be more active online. There are a lot of people now that browse the Net and use emails.

From the interviews it became clear that ICTs are used as a support for the design and production of crafts in Egypt, but until now are not a major marketing and sales tool. With the spread of ICTs, mobile phones, and the Internet in particular, this could change over time and should not be dismissed, but a realistic perspective should be maintained as to the context these women are working and marketing in.

\section{The challenge of limited demand for local crafts in the Egyptian market}

In Egypt there is not much daily demand for locally made crafts, other than the simple, low-cost crafts used by lower income Egyptians, such as pottery to hold water, palm reed baskets, and iron works used in rural and semi-rural areas. These types of crafts are not covered in this research as they fall under the category of daily used objects which have a slim profit margin and are not marketable in their present crude form to other market niches. Most women in this study are involved in crafts that have lost their traditional use due to western styled modernization and have been relegated to the souvenir category.

The dress and interior design fashion in Egypt are geared towards Western models. Egypt has neither developed a modern design style using traditional motives like South Africa nor pioneered a contemporary design school like the Scandinavians. Nor did it maintain and cultivate its traditional crafts on a national scope like the textile industry in Senegal and Morocco, where the Caftan is still the national dress. There were short attempts by local designers to modernize the Islamic style in interior design, but these efforts remained at the level of well known designers and the elite, with most of the clientele in rich oil producing Arab countries. This style was not mainstreamed to the middle income brackets where the volume demand is. The leading Egyptian Décor magazine "Beity" ("My House") shows the design trends of the affluent who are beginning to incorporate Egyptian and Islamic elements into their homes. Yet, at present these trends are financially out of reach for most Egyptians. ${ }^{3}$ Beity's showcase-houses though are a model for how traditional crafts could be used for a local design trend that could be adjusted to different income brackets.

A modern Egyptian design theme would allow for a more integrated craft production line where different crafts are combined to create design themes; this would include textiles, wood, metal, and glass, among other specialties. The

\footnotetext{
${ }^{3}$ A middle income Egyptian referred to the magazine to the researcher as offensive in its display of expensive, out of reach décor.
} 
creation of such a design trend would create local markets for female artisans and would revitalize some of the traditional crafts in Egypt.

An adequate national market would be a starting point for handicrafts marketed through ICTs, in this case mobile phones could be even more viable than the Internet. Online marketing, though, would still have its clientele in the higher income brackets.

\section{Quality and design as marketing ingredients}

The issue of quality as a prerequisite for successful sales came up with donors and with international NGOs that market crafts. At present, most products bought from the crafts women are not immediately sellable due to their poor finishing. The merchants are finishing many of the products and are reaping wide margins of profit by doing this. For example, they will take an exquisite, but frayed piece of stitching, line it, sew the edges and the piece will sell at a much higher price.

COSPE trained Siwan women artisans in quality improvement, such as finishing techniques. But COSPE experienced resistance by most women to clean up their embroideries because they had many household duties that needed their time and attention. So they set up a second production line with women sewers to finish the embroidery work. The multiple duties the craftswomen face in the domestic sphere prevents them from producing higher end finishes - despite the provided training and the promise of reaping better financial returns.

The use of professional designers has improved the marketability of some Egyptian crafts, putting a modern spin on them with stylish colours and by following fashion trends. El-Bashayer revived its crocheting by hiring a well known Egyptian designer with whose help the organisation improved its marketing quota through offering more attractive pieces. Their products range from floor length curtains, bedspreads, bath towels, to infant and adult clothes.

Negada, a weaving community in the Qena governorate at the Egyptian southern border, is another example of the importance of incorporating a designer in the production process. Negada shawls had been traditionally marketed to the Sudan, but with the civil war and the hardening of the Egyptian-Sudanese border the weavers lost their clientele and their main market. The craft was dying out. The Canadian International Development Agency (CIDA) funded a one-year project where a French designer was brought in to revive the fading weaving tradition. The designer worked directly with the weavers bringing in new colour combinations and weaving themes. Despite the project's short duration, the local weavers quickly absorbed the new designs and were able to expand their markets to Cairo and beyond.

Currently Negada fabrics are sold in an upscale outlet in Garden City, Cairo, with Japanese expatriates as its main clients. The prices of the Negada pieces are high, not affordable for most Egyptians. If the Negada experience could be adapted to the tastes of Egyptians and the prices adjusted to domestic consumers, 
even if at the higher income levels, there could be a wider domestic market for these textiles.

ICTs are an excellent tool to showcase product diversity, design ideas, and quality issues to local female producers. As the saying goes, a picture is worth a thousand words, and this technology enables to bring the message home in a visual manner.

\section{Challenges for Egyptian crafts in the global market}

Internationally, Aid to Artisans (ATA) ${ }^{4}$ is a leading US based fair trade organisation. ${ }^{5}$ I met with the ATA board of directors, the marketing division, and visited their booth at the NY Gift Fair. ATA's products are attractively exhibited; a big difference from the quality and display of crafts in Egypt like the Fair Trade Egypt shop. In general the displays at the NYC Gift Fair were sophisticated in their designs, colour coordination, quality, and presentation. One has to take into consideration that the designs and colour schemes change from year to year. Seasonal items are marketed far in advance and a trend watch is critical at this level of marketing. In addition to be on the forefront of fashion trends, the crafts have to be financially competitive while maintaining the highest quality standards. This is a big ordeal, as - in their current state - most Egyptian crafts are not competitive internationally design and quality wise and their prices are midranged at best.

In terms of the main competition to Egyptian goods, in fair trade terms and beyond, the Moroccan crafts are predominant and had an early entry into the global market, followed by Jordanian goods. Both the Moroccan and the Jordanian governments have been promoting handicraft exports for many years and have gained a foothold in the global market. The Egyptian government has only recently begun pushing crafts trade. It was obvious that this environment was not something a simple Egyptian craftswoman, or even a cooperative without external help, could handle. Even COSPE has been struggling to successfully export selected Egyptian crafts to Italy during their ten years of operation.

South Africa is a successful example of taking African crafts and designs to a broad based local and global clientele. This was possible by marketing the African "way of life" through interior design, literature, and a widening and increasingly sophisticated émigré base. One has only to step into Johannesburg airport's two dominant crafts shops: Inside Africa and the newly established Into Africa, to experience the designs, colours, and exquisite arrangements that have made this design style famous. There is no equivalent to this vibrant shopping experience in Egypt. South Africa was able to establish its design elements in the highest echelon of international interior design which has increased its marketability and

\footnotetext{
${ }^{4}$ ATA's website is a good starting point to explore the richness of global craft production and marketing, see: http://aidtoartisans.org/home.php

${ }^{5}$ ATA is also heavily supported by USAID funds.
} 
appeal. The South African design is also popular within the country itself, this way it has a varied purchasing base.

\section{Selling crafts online}

After having explored the macro-environment for the crafts trade in Egypt and globally, this chapter asks: what are the issues and challenges facing a woman who wants to establish an online crafts selling business? Are there other ICT tools beside the Internet that could help women market crafts? Are there examples from other fields that could guide economic development practitioners and decisionmakers in invigorating trade in the crafts sector?

Davis [3] led a carpet selling project: Women Weavers Online: rural Moroccan women on the Internet. The project sold carpets traditionally made by Moroccan women through a website without the women leaving their respective villages. Some of these villages were in remote and isolated areas of Morocco. Davis shows that it was possible for her project to market and sell rugs through the Internet. Davis' article, however, also shows that establishing the website and marketing the rugs was based on the existence of the author who is a well-educated American and who used her social relations, her language, and technological skills to enable this commercial online outlet. Davis does not account for her expenses in the financial spreadsheet that shows a marginal profit for the women weavers through the international sale of their rugs. Not accounting for Davis' actual cost gives an unrealistic financial and technical viability to the initiative that could not have existed without her presence. This author is not optimistic about the possibility of training and recruiting a local person to substitute her to enable sustainability of the initiative.

\section{Suzanne the online crafts entrepreneur}

Yet, given the right skills and circumstances it is possible to have a crafts selling business via the Internet as shown by the example of a young woman from Cairo, who is exporting handicrafts overseas through her website. Suzanne is a middle-class, single woman who, as is the custom in Egypt, lives with her parents. She attended a private, foreign language school and has a B.A. in Finance. After holding odd jobs for several years, she decided to establish her own business marketing Egyptian souvenirs at fairs and by establishing a website to sell internationally.

I am online daily for hours - my parents are constantly chiding me for running up the phone bill. ${ }^{6}$ I search for wholesale traders online and have been using chat rooms and social networking sites like Facebook and others to find merchants. I have good and bad experiences, but selling needs a stick-to-it attitude and I have that in

\footnotetext{
${ }^{6}$ In Egypt Internet use is paid through the phone bill.
} 


\section{bundles. Overall I have been successful in the end. I am now dealing} with a trader in California whom I export bigger quantities to.

Despite making business contracts, Suzanne has been discouraged by her sister and her parents in her commercial enterprise. For them her work is very consuming and requires a lot of upfront money, especially for the IT services, and more than it has brought in until now, but Suzanne is persistent.

Business is like that you have to give it time. I have made constant progress since I began and I am optimistic about this enterprise.

She has a website ${ }^{7}$ that she constantly upgrades. Suzanne excelled in finding back-office solutions to her e-business. One of the main challenges was the lack of e-commerce in Egypt, which made it impossible to charge a customer's credit card through an online transaction.

Egypt is planning to have e-commerce in the future, though an exact date has not been set. Currently, the Information Technology Industry Development Agency (ITIDA) ${ }^{8}$, established by Law 15 in 2004, is responsible for e-signatures, e-commerce, and e-business activities in Egypt. Paving the way for e-commerce, e-signatures were established by the executive regulations, decree no. 109 of 2005. E-signatures are a cornerstone for e-commerce because the electronic authentication of signatures is essential for e-financial transactions. ${ }^{9}$

Under these circumstances Suzanne had to find a creative solution to be able to offer credit card transactions on her site. Having a credit card payment option is a necessity to be competitive in today's online craft business. Her site has a selling link to a US company, 2Checkout.com, that "is the online distribution center for over 300,000 tangible or digital products and services. 2CO provides turnkey ecommerce solutions to thousands of business customers around the world."10

In addition to finding alternative solutions to be able to sell her wares, finding reliable and cost effective transportation for her micro-business was a major challenge for Suzanne. She researched all shipping and air companies and options to find economic shipping rates from a dependable company she could trust in handling the goods with care.

Suzanne had also dealt before with customs to be able to export her goods, which proved to be quite complex, and she had to hire a person who knew how to

\footnotetext{
${ }^{7}$ See: http://www.charisma-arts.net/

${ }^{8}$ The Information Technology Industry Development Agency (ITIDa) online available at http://www.itida.gov.eg/index.asp

9 To pave the way for broader applications of online transactions the Egyptian government has introduced some domestic e-financial transactions for citizens. For example, phone bills can be paid through the e-government portal, a bi-lingual Arabic-English site, with a credit or debit card. Credit/debit card use is limited in Egypt and are mostly restricted to higher income levels, but the availability of such e-government service tools could open their use in future by the average citizen. At present the economy is mostly cash based and computer diffusion is still low as is Internet use. All these factors restrict the actual use of such e-financial services.

${ }^{10}$ See: https://shop.2checkout.com/2co/index
} 
navigate the system. She now uses Aramex ${ }^{11}$, as this company offered the most convenient solution for her micro-business.

Customs are handled by Aramex in Suzanne's case, but customs are a major issue with most import-exporters. At the NY Gift Fair an American merchant told the author that the US customs regulations change each year and that this is problem for every exporter and importer as they never know what is permitted to be imported the following year. They make a deal to import a big lot of textiles, for example, only to find out that import regulations to bring them to the US has changed preventing them to import these textiles. Sometimes they circumvent this change by naming the import a different name and they get away with that. But it is not a guaranteed solution. Therefore, most merchants have contact points at the customs offices to know about new regulations as soon as possible, but problems regarding these changes still come up.

Suzanne is the epitome of persistence and the creator of inventive solutions that enabled her, through trial and error, to establish a successful online crafts selling business. However, the setting up of such a website requires a highly enterprising attitude, combined with education and technical skills or the money to afford outside technical assistance. Suzanne's command of English is excellent too - the absence of language skills with most of the artisan women interviewed is a major obstacle to use the Internet for international trading. In Suzanne's case she has been aided by her family's financial support; as a single, not yet married woman in Egypt she is expected to be, if not fully supported financially by her parents, then at least in great part so. This freed Suzanne from worrying about living expenses like shelter and food, which could have affected the input she has given and still is giving to her entrepreneurial project. Suzanne has a computer at home and has been an active Internet user for years before starting her enterprise. Her IT skills are quite sophisticated which made it possible for her to use the Internet as a marketing resource.

\section{Conclusion}

The research began as a quest by ArabDev to fulfil the demands of some craftswomen and crafts related not-for-profits to use ICTs, especially the Internet to widen their markets. A pragmatic step-by-step approach to marketing and selling online and possibly through other ICTs, like mobile phones, was taken. The research showed the difficulties facing women artisans and women involved in the crafts trade to export Egyptian crafts competitively to global markets. The

\footnotetext{
${ }^{11}$ Among its services Aramex provides US and UK based mailboxes to its customers. With this system a customer has a US or UK based address to which they can send and receive mail through local transport charges. Then the contents of the mailboxes are shipped in bulk three times a week, reducing shipping costs for the mailbox owners. The Aramex mailbox option is the closest a micro business can come to wholesale shipping. Though the shipping destination is only Cairo in Egypt for example, anyone living in farther out governorates would need to arrange additional domestic transport. Due to the Aramex service offers, international trading for micro- and small enterprises has been made easier by allowing them to buy and sell as if they had a foreign domicile.
} 
barriers involve literacy, language skills, technical know-how, knowledge of how to navigate the regulatory and legal aspects of the export trade, quality control, transport requirements, and the availability of e-commerce..

This study began with the premise that ICTs could offer access to wider markets and higher profit retention for Egyptian crafts women. The research findings, however, showed gaps with the design, production, and quality of the crafts that determine the competitiveness of Egyptian handicrafts and these issues have a greater impact on sales than the use of ICTs for marketing. The

Internet has been a resource for some of the interviewed women nonetheless. Among those women who use ICTs, several were formerly craftspeople and then increased their education, including computer, and Internet skills, and changed their earning venue to a clerical job.

Craft production is often abandoned once a woman has marketable ICT skills. More income can be earned through clerical work than through handicrafts. Some craftswomen who made it "up the ladder" through increased education became supervisors for other craftswomen but stopped their direct production of crafts. In Siwa, a computer trainer from a local development organisation who works at the local school continues to do the traditional Siwan stitching in the evenings for additional income. Yet she does not combine her artisan work with her IT skills. Overall, examples of craftswomen using ICTs were few and not the norm.

Suzanne's example shows that while some women, mostly the more educated and privileged, could indeed benefit from utilizing ICTs in their entrepreneurial quest, most Egyptian crafts-women face prohibitive barriers to use this technology.

There are few examples where craftswomen are directly involved in marketing their wares through the Internet in Egypt. Email is used by craft producing NGOs as part of the selling process, but not as a marketing tool. Even mobile phones were not a main vehicle used by women in the marketing cycle.

ICT enabled entrepreneurship for the female crafts sector is not yet realistic, especially if it is geared towards selling globally. There is a big difference between a woman selling her wares at a local market, while she sits on the sides of the street, and a woman marketing to outside venues, especially through the Internet. One cannot extrapolate the development of a street vendor to an online merchant. A business to consumer export model cannot compete with a wholesale website. The tactile nature of crafts lends them to more traditional marketing venues like craft exhibits.

The research shows that the global crafts market is a highly competitive sphere both in price and quality and that exporting is not the straightforward answer to craft marketing in the Egyptian case. Despite this fact, ICTs can be a vehicle for the marketing of crafts for entrepreneurially inclined women, as is shown in by an example in this chapter. Yet, the same is not true for the larger numbers of low income women. For these women to benefit from marketing through ICTs it would need to be institutionalized into a collective enterprise that handles the various stages of product design, quality control, and marketing. 
ICTs though make a good venue for quality promoting education, for a more creative design process, and to give local craftswomen a taste of global wares so that they have more incentives to improve their crafts even for the local market.

The study found that the most promising market for local craftswomen would be a domestic outlet. If Egypt could establish a broad base of local demand for an Egyptian style in interior design, for example, lots of the traditional crafts, now at the brink of extinction, could be incorporated into products that are part of this revived design style. The establishment of such a market depends on creating demand and the making of crafts at various price ranges available to the Egyptian consumers. Decision makers and social leaders are the prime vehicles for creating more demand for Egyptian crafts in the interior design and fashion circles. This in turn would make it easier for craftswomen to market their crafts either individually, collectively, or through an intermediary and the use of ICTs would be a promising tool to help them in this endeavour.

\section{Acknowledgements}

This research was made possible by grants from the International Development Research Centre (IDRC) through the GRACE project and the Ford Foundation.

\section{References}

[1] Alsever, J. (2006). Fair prices for farmers: Simple idea complex reality, New York Times, March 19, available online: http://www.nytimes.com/2006/03/19/business/yourmoney/19fair.html.

[2] Poojary, C.M. (1996). What creates an entrepreneur? Some observations from a micro study, Journal of Entrepreneurship, Sage Publications, 5 (2), 253-60.

[3] Davis, S.S. (2004). Women weavers online: rural Moroccan women on the internet. Gender, technology and development, 8(1), 53-75.

[4] Mueller, S.D. (2006). Rural development, environmental sustainability, and poverty alleviation: A critique of current paradigms, DESA Working Paper, No. 11, January 2006, available online: http://www.un.org/esa/desa/papers/2006/wp11_2006.pdf.

[5] Ofreneo, R. P. (2006). Problematizing microfinance as an empowerment strategy for women living in poverty: Some policy directions, Gender, Development and Technology Journal of the Asian Institute of Technology (AIT), Bangkok, available online:

http://www.upd.edu.ph/ cswcd/webpages/DOCUMENTS/facultypublications/PUBLI CATIONS_Ofreneo2.pdf. 